\title{
APPENDIX III. RADIOCARBON DATING OF SEDIMENTS FROM THE CARIACO TRENCH, DEEP SEA DRILLING PROJECT SITE 1471,2
}

\author{
Elliott C. Spiker, U.S. Geological Survey, Reston, Virginia \\ and \\ Bernd R. T. Simoneit, Institute of Geophysics and Planetary Physics, \\ University of California at Los Angeles, Los Angeles, California
}

\begin{abstract}
Samples from Holes 147, 147A, and 147B have been dated by the radiocarbon method; ages ranged to 27,000 years ago at about 20 meters sub-bottom. The sedimentation rates were approximately $50 \mathrm{~cm} / 10^{3} \mathrm{y}$. for the last 5000 years and 10 to $75 \mathrm{~cm} / 10^{3} \mathrm{y}$. prior to that.
\end{abstract}

\section{INTRODUCTION}

The Cariaco Basin, or Trench, is a fault depression in the Venezuelan continental shelf which has anaerobic water below 360 meters. Four holes were drilled on the saddle separating the eastern and western deeps (147: $10^{\circ} 42.48^{\prime} \mathrm{N}, 65^{\circ} 10.48^{\prime} \mathrm{W}$; $147 \mathrm{~A}, 147 \mathrm{~B}$, and $147 \mathrm{C}$ : $10^{\circ}$ $42.68^{\prime} \mathrm{N}, 65^{\circ} 10.45^{\prime} \mathrm{W}$, water depth $892 \mathrm{~m}$; Edgar et al., 1973). Most of the material recovered from Holes 147A, $147 \mathrm{~B}$, and $147 \mathrm{C}$ was frozen for organic geochemical studies. Since there were only two known radiocarbon dates for a piston core taken in the Trench (Heezen et al., 1958), it was of interest to determine further dates for the cores at Site 147 in order to provide a time frame for the recent sedimentation history.

\section{METHODS}

Short sections of core material were sampled from the frozen organic geochemistry collection (Holes 147A and 147B); four samples, for carbonate dating only, were obtained from the working half of cores from Hole 147.

Radiocarbon measurements were performed on the carbonate fraction and/or the organic carbon fraction, depending on sample size and carbon content. The carbonate was extracted by acid leaching with dilute $\mathrm{HCl}$ in a vacuum system. The residual sample material was filtered, washed, and dried. The organic carbon was next extracted by combustion in a vacuum system. The ${ }^{14} \mathrm{C}$ activity was analyzed by the acetylene gas counting method (modified after Suess, 1954) at the U.S. Geological Survey, Reston, Virginia. Sample activities have not been corrected for isotope fractionation with a ${ }^{13} \mathrm{C}$ measurement. Assuming a $\delta^{13} \mathrm{C}$ value of zero and -21 per mil for the carbonate and organic fractions, respectively, this correction would add approximately 412 years to each carbonate date and 65 years to each organic date. The true age, however, may be as much as 1000 years younger than this corrected value, owing to the possible incorporation of reworked material as well as the marine reservoir effect (the radiocarbon deficiency of ocean waters) (Broecker et al.,1960). The dates were calculated relative to the National Bureau of Standards oxalic acid standard activity (Stuiver and Polach, 1977).

\section{RESULTS}

The radiocarbon data for the organic and the carbonate carbon fractions of the samples are given in Table 1

\footnotetext{
1 Initial Reports of the Deep Sea Drilling Project, Volume 66.

2 This appendix has been placed into Volume 66 for convenience. It presents data supplementary to DSDP Leg 15, Site 147, Cariaco Trench.
}

Table 1. Results of radiocarbon analyses of samples from the Cariaco Trench, DSDP Site 147, and estimated ages.

\begin{tabular}{|c|c|c|c|c|}
\hline $\begin{array}{c}\text { Sample } \\
\text { (interval in } \mathrm{cm} \text { ) }\end{array}$ & $\begin{array}{l}\text { Sub-bottom } \\
\text { Depth } \\
(\mathrm{m})^{\mathrm{a}}\end{array}$ & $\begin{array}{c}{ }^{14} \mathrm{C} \mathrm{Age} \\
(\text { organic C) } \\
\text { (years ago } \pm 1 \sigma \text { ) }\end{array}$ & $\begin{array}{c}{ }^{14} \mathrm{C} \mathrm{Age} \\
\text { (carbonate) } \\
\text { (years ago } \pm 10 \text { ) }\end{array}$ & $\begin{array}{l}\text { Estimated Age } \\
\text { Assuming } \\
50 \mathrm{~cm} / 10^{3} \mathrm{y} \text {. }\end{array}$ \\
\hline $147-2-2,43-50$ & $6.0-9.5$ & \multicolumn{2}{|c|}{$4600 \pm 90^{b}$} & 15,500 \\
\hline $147-2-2,60-65$ & $6.1-9.4$ & $-^{c}$ & $5150 \pm 200$ & 15,500 \\
\hline $147-2-4,112-116$ & $9.6-13.3$ & - & $17,920 \pm 300$ & 22,900 \\
\hline $147-3-1,123-130$ & $15.3-19.3$ & \multicolumn{2}{|c|}{$31,800 \pm 700^{b}$} & 34,600 \\
\hline $147 \mathrm{~A}-1-1,46-50$ & 0.5 & $1560 \pm 200$ & - & 1000 \\
\hline $147 \mathrm{~A}-1-1,120-140$ & 1.3 & $3070 \pm 95$ & $3270 \pm 85$ & 2600 \\
\hline $147 \mathrm{~A}-2-1,130-142$ & $2.9-9.4$ & $10,790 \pm 250$ & $10,970 \pm 250$ & 13,300 \\
\hline $147 \mathrm{~A}-2-2,0-15$ & $3.1-9.6$ & $11,230 \pm 250$ & $11,380 \pm 250$ & 14,000 \\
\hline $147 \mathrm{~A}-2-3,113-130$ & $4.2-12.2$ & - & $25,490 \pm 360$ & 16,400 \\
\hline $147 \mathrm{~A}-2-3,120-135$ & $4.3-12.3$ & - & $26,300 \pm 470$ & 16,600 \\
\hline $147 \mathrm{~B}-1-2,65-75$ & $4.2-5.2$ & - & $5080 \pm 80$ & 9700 \\
\hline $147 \mathrm{~B}-1-2,70-75$ & $4.2-5.2$ & $6200 \pm 1000$ & - & 9700 \\
\hline $147 \mathrm{~B}-2-2,38-52$ & $14.9-15.5$ & - & $2030 \pm 60$ & 30,400 \\
\hline $147 \mathrm{~B}-2-3,1-7$ & $16.0-16.5$ & $2620 \pm 700$ & - & 32,500 \\
\hline $147 \mathrm{~B}-2-3,20-35$ & $16.3-16.8$ & $2120 \pm 95$ & $2020 \pm 75$ & 33,100 \\
\hline $147 \mathrm{~B}-2-5,125-138$ & $20.3-20.8$ & - & $26,830 \pm 370$ & 41,100 \\
\hline $\begin{array}{l}\text { V12-99 (Heezen } \\
\text { et al., 1959) }\end{array}$ & 3.0 & 8000 & - & 6000 \\
\hline $\begin{array}{r}\text { V12-99 (Heezen } \\
\text { et al., 1959) }\end{array}$ & 4.6 & 11,200 & - & 9200 \\
\hline
\end{tabular}

a Two values indicate the range of depth assignment, using the DSDP convention of measuring from the top of the core down or from the core catcher up.

The total carbon (organic + carbonate fractions) was dated.

${ }^{c}$ Insufficient sample or not determined.

and the results plotted in Figure 1. The data for Hole $147 \mathrm{~A}$ show a change in the sedimentation rate from approximately $50 \mathrm{~cm} / 10^{3}$ y. to $10 \mathrm{~cm} / 10^{3} \mathrm{y}$. about 10,000 years ago. The data for Hole 147B show an anomaly: Samples 147B-2-2, 38-52 cm, 147B-2-3, 1-7 cm, and 147B-2-3, 20-35 cm cluster at about 2000-2600 years ago, completely outside the other data (Fig. 1). The sedimentological features of the Holocene section in Hole 147 do not include slump features or other evidence of redeposition. Anomalous major ion concentrations of pore fluids in Sample 147B-2-2 were observed (Broecker, 1973), however. Broecker determined the ${ }^{230} \mathrm{Th} /$ ${ }^{234} \mathrm{U}$ age of the solid fraction of this sample to be less than 3000 years old and interpreted it to be "fall in" material.

Contamination during coring could adequately explain the anomalous radiocarbon results. Alteratively, it is possible that these sections were simply mislabeled on shipboard. Sections 147B-2-1 and 147B-2-4 were not dated and may also be anomalous. If we assume that the ${ }^{14} \mathrm{C}$ age of Sample 147B-2-5, $125-138 \mathrm{~cm}$ is correct, 


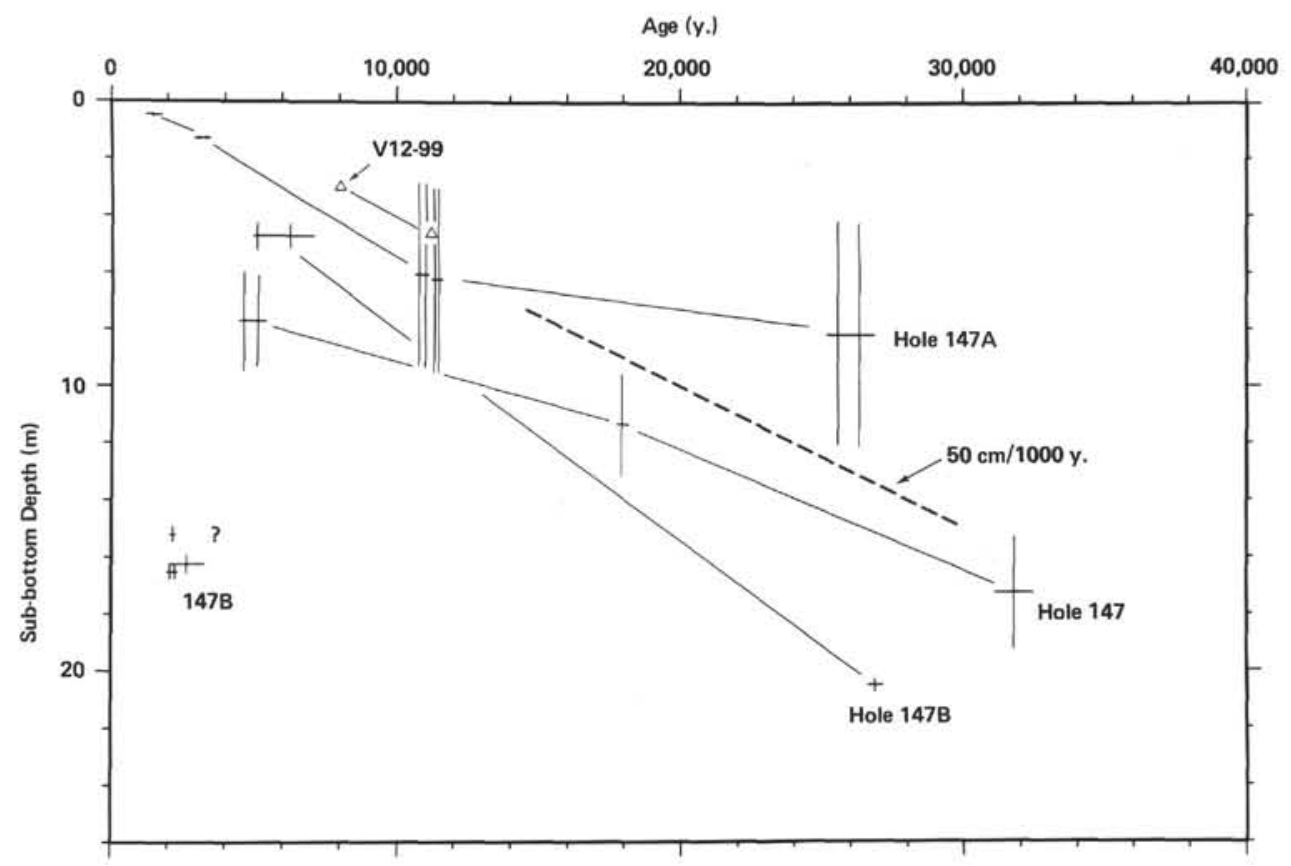

Figure 1. Radiocarbon ages of sediments from the Cariaco Trench, DSDP Site 147 and Vema piston core V12-99.

then the sedimentation rate extrapolates to a reasonable value: about $75 \mathrm{~cm} / 10^{3} \mathrm{y}$. for Hole 147B.

In order to corroborate further the anomaly of Core 147B-2, four samples from the working half of core from Hole 147 were analyzed. These data indicate a sedimentation rate of about $20 \mathrm{~cm} / 10^{3} \mathrm{y}$. Hole 147 is located approximately 370 meters south of Holes $147 \mathrm{~A}$ and 147B. Also shown in Figure 1 and Table 1 are two dates reported from a piston core (V12-99) taken by the $\mathrm{R} / \mathrm{V}$ Vema about $4 \mathrm{~km}$ southwest of Hole 147 in the middle of the ridge (Heezen et al., 1958, 1959). The sedimentation rate for V12-99 is approximately $50 \mathrm{~cm} / 10^{3}$ $\mathrm{y}$, and this value has been used to estimate the sedimentation rates for the Hole 147 cores (cf. Table 1, Edgar et al., 1973). Based on data from this work, the sedimentation rate to about 10,000 years ago is approximately 50 $\mathrm{cm} / 10^{3} \mathrm{y}$. (an average), whereas prior to that the rates vary from 10 to $75 \mathrm{~cm} / 10^{3} \mathrm{y}$.

\section{CONCLUSION}

Samples from Holes 147, 147A, and 147B have been dated by the radiocarbon method to 27,000 years ago at a sub-bottom depth of about 20 meters. The sedimentation rates are variable and average about $50 \mathrm{~cm} / 10^{3} \mathrm{y}$. to about 10,000 years ago and are 10 to $75 \mathrm{~cm} / 10^{3} \mathrm{y}$. prior to that. Sections 147B-2-2 and 147B-2-3 appear to be contaminated or mislabeled.

\section{ACKNOWLEDGMENTS}

We thank J. Gieskes, M. Rubin, and E. T. Sundquist for helpful discussions and criticism and M. L. Kelley for analytical assistance. This chapter is Contribution No. 2030 from the Institute of Geophysics and Planetary Physics, University of California at Los Angeles.

\section{REFERENCES}

Broecker, W., 1973. Interstitial water studies, Leg 15-introduction and summary. In Heezen, B. C., MacGregor, I. D., et al., Init. Repts. DSDP, 20: Washington (U.S. Govt Printing Office), 751755.

Broecker, W., Gerard, R., Ewing, M., et al., 1960. Natural radiocarbon in the Atlantic Ocean. J. Geophys. Res., 65:2903-2931.

Edgar, N. T., Saunders, J. B., et al., 1973. Site 147. In Edgar, N. T., Saunders, J. B., et al., Init. Repts. DSDP, 15: Washington (U.S. Govt. Printing Office), 169-178.

Heezen, B. C., Menzies, R. J., Broecker, W. S., et al., 1958. Date of stagnation of the Cariaco Trench, Southeastern Caribbean. Geol. Soc. Am. Bull., 69:1579.

1959. Stagnation of the Cariaco Trench. In Sears, M. (Ed.), International Oceanographic Congress: Washington (Amer. Assoc. Adv. Sci.), pp. 99-102.

Stuiver, M., and Polach, H. A., 1977. Reports of ${ }^{14} \mathrm{C}$ data. Radiocarbon, 19:355-363.

Suess, H. E., 1954. Natural radiocarbon measurements by acetylene counting. Science, 120:5-7. 